\title{
Covid-19 impact on employment and skills for the labour market
}

Sue Enfield

Institute of Development Studies

February 2021

\section{Question}

In the middle-income countries of Mexico, Malaysia, Indonesia, Philippines and South Africa:

- Which are the sectors in which COVID-19 has had a significantly negative impact on employment or self-employment, particularly for women and youth?

- Has COVID-19 increased the demand for particular skills as the labour market adapts? If so, which are the sectors and occupations in which this is evident. (Research will focus on the emerging opportunities for women, youth and other excluded groups).

\section{Contents}

1. Summary

2. Negative impacts on employment

3. Impact on the labour market in specific countries

4. Changing skill demands

5. References

The K4D helpdesk service provides brief summaries of current research, evidence, and lessons learned. Helpdesk reports are not rigorous or systematic reviews; they are intended to provide an introduction to the most important evidence related to a research question. They draw on a rapid deskbased review of published literature and consultation with subject specialists. 


\section{Summary}

The pandemic is not over, therefore assessment of labour market disruptions involves a high level of uncertainty. It was a novel effect of this crisis, compared to the financial crisis of 2008-9, that job loss has been more intense among self-employed workers than among wage earners, and deeper among informal than formal workers. The impact from COVID-19 on the labour market has been greatest for those in precarious employment, at an early stage in their career or engaged in the informal sector. The informal sector has suffered from the consequences of lockdown measures that have reduced mobility and transport, curtailed informal markets and small-scale enterprises often run by independent contractors.

This literature review draws from academic and grey literature, published largely as institutional reports and blogs. Most information found considered global impacts on employment and the labour market with the particular impact for the very high numbers of youth, women, migrant workers, and people with disabilities who are more likely to be employed in the informal sector.

There has been high negative impact on the informal sector and for precariously employed groups. The informal labour market is largest in low and middle-income countries and engages 2 billion workers (62 per cent) of the global workforce (currently around 3.3 billion) (World Bank, 2020). Particularly in low- and middle-income countries, hard-hit sectors have a high

proportion of workers in informal employment and workers with limited access to health services and social protection. Economic contractions are particularly challenging for micro, small and medium enterprises to weather. Reduced working hours and staff reductions both increase worker poverty and hardship. Women, migrant workers, and youth form a major part of the workforce in the informal economy since they are more likely to work in these vulnerable, lowpaying informal jobs where there are few protections, and they are not reached by government support measures. Young people have been affected in two ways as many have had their education interrupted; those in work these early years of employment (with its continued important learning on the job) has been interrupted or in some cases ended.

Early in the pandemic (April 2020) key sectors particularly affected by severe declines in economic output include retail trade, accommodation and food services, and manufacturing (ILO, 2020). Women are particularly affected by both the supply and demand side shocks of the crisis given their disproportionate responsibilities for caring for children and the ill; and given the vulnerability of the sectors in which they predominate that have experienced larger initial job losses (Carranza et al, 2020). Many predominantly female and public-facing sectors were also affected early on - fashion, retail, hospitality, travelling, leisure.

Limited country specific information was found. Country studies broadly confirm the international trends and illustrate inequity of impact. Already vulnerable workers are most affected by

- large reduction of hours worked and income from labour

- up to $40 \%$ decline in active employment

- huge impact on precarious jobs in sectors that lack formal employment conditions (such as call centre staff, or those engaged in supply chains dependent upon outside contractors from a second county)

- independent workers in the informal sector have been hit once by loss of trade during lockdowns and again as the informal market becomes more competitive as substantial layoffs push people out of the formal sector and into informal work. 
Detailed evidence about post pandemic demand was found in just one study (ILO,2019) of the anticipated changes in skills for the labour market in response to the need to decarbonise economies. Equivalent analysis for the change in labour market sectors and skills demand, was not found for a post pandemic economic recovery. Discussion tends to be general - noting that the global labour market was already challenged to respond to pressures of the growing youth population, the rise of computing technologies and the political and social imperatives for countries to decarbonise their economies. Covid-19 has made this 'tri-lemma' more urgent still.

COVID-19 has highlighted the choice between two possible recovery pathways: one which is low-carbon, and one which locks in catastrophic climate change. The low-carbon transition will require adapting and changing existing sectors and industries, creating new occupations requiring new skills, as other skills become obsolete (Genscu et al, 2020). The low carbon transition implies significant changes in the type of skills needed and the jobs available in specific locations.

Future policy making and training to reskill laid off workers or to improve overall quality of the labour force through increasing investment in education, should also consider changes anticipated as some jobs are digitised. It is crucial to get the timing right for tailored support to the COVID-19 generation of workers. The longer they are out of work or underemployed, the more difficult it will be to reverse the adverse impacts of the crisis.

\section{Negative impacts on employment}

\section{Overview}

The pandemic is not over, therefore assessment of labour market disruptions involves a high level of uncertainty. After the recession caused by the financial crisis (2008-9) recovery in employment and income from labour was slow. This contributed to a negative cycle further slowing economic recovery, and youth unemployment has never managed to recover fully from the crisis. Hence, although the economic effects of the pandemic are still emerging there is good reason for keeping abreast of analysis (Lee et al, 2020). It may be possible to anticipate policy measures that would avoid repeating the aftermath of the 2008-9 fiscal crisis.

The effects from the pandemic are not standard in terms of habitual ways of measuring employment or unemployment. Where Governments have stepped in with social support packages, unemployment does not indicate the actual scale of disruption for workers. Many people have kept their jobs but are not working (therefore they are counted as being employed) or lost their work but are not searching for jobs because of care or other personal responsibilities (therefore they are counted as inactive) or are working shorter hours (therefore counted as employed but are less productive). Large numbers of workers are working shorter hours, or similar hours for less pay, or in circumstances which now pose greater risk to their health.

\section{Sectoral impact}

Early in the pandemic (April 2020) key sectors particularly affected by severe declines in economic output included retail trade, accommodation and food services, and 
manufacturing (ILO, 2020). Lockdowns and related business disruptions, travel restrictions, school closures and other measures to contain the pandemic have had sudden and drastic impacts on workers and enterprises. These sectors have a high proportion of informal workers (see below) and workers in the gig economy (a labour market characterised by the prevalence of short-term contracts or freelance work). While the economic impacts of the pandemic are felt across the board, continuing operations is particularly challenging for micro, small and medium enterprises, as these have fewer effective instruments at their disposal to manage shocks (Carranza et al, 2020). For similar reasons, non-wage workers and wage workers on temporary contracts or in the informal sector, are also disproportionally affected.

\section{Workers in the informal economy}

The impact of the crisis has fallen with unequal severity and the impacts on income and poverty for informal workers are considerable. The informal labour market is largest in low- and middleincome countries (World Bank, 2020). Particularly in low- and middle-income countries, the hardhit sectors have a high proportion of workers in informal employment and workers with limited access to health services and social protection. This puts these workers at greater risk of decline into poverty and of facing considerable future challenges for regaining their livelihoods in the post pandemic recovery. The global workforce is currently around 3.3 billion, of which around 2 billion workers (62 per cent) are engaged in the informal economy now facing new and higher risks. Out of this workforce almost 1.6 billion are estimated to be significantly impacted by the crisis, due to lockdown measures or because of working in high-risk sectors (Lee et al, 2020):

- Over two in three informal workers are estimated to have been impacted by the crisis

- Earnings are estimated to have fallen by over 60 per cent

- Informal workers are ineligible for the majority of support measures

- Self-employed, temporary and part-time workers are less protected by existing safety nets such as job retention schemes or unemployment insurance

- Informal workers are concentrated in sectors most affected.

Migrant workers are particularly vulnerable within the informal economy since they are more likely to work in at risk, low-paying informal jobs where there are few protections, and they are not reached by government support measures (Gencsu et al, 2020). Women with disabilities are more likely to be in informal work due to multiple and intersecting forms of discrimination (Women Enabled International, 2020).

\section{Impacts for Women and Youth}

Impacts on the economy, while widespread, can be gender-differentiated. Women are particularly affected by both the supply and demand side shocks of the crisis given their disproportionate responsibilities for caring for children and the ill; and given the vulnerability of the sectors in which they predominate that have experienced larger initial job losses (Carranza et al, 2020). Women form a majority of health workers in nearly all G20 countries ${ }^{1}$; and in many predominantly female and public-facing sectors that have been affected early on - fashion, retail, hospitality, travelling, leisure for example (Carranza et al, 2020: 5).

${ }^{1}$ Mexico \& South Africa included 
Despite some progress over previous decades, gender gaps were still considerable and persistent in labour markets around the world before the onset of the COVID-19 crisis (including gaps in labour force participation, wages and quality of employment). In the light of these pre-crisis gender inequalities, the COVID-19 crisis is disproportionately affecting women workers in these ways (WOW, 2020:4)

- 40 per cent of all employed women around the world (almost 510 million) work in hard-hit sectors (compared with 36.6 per cent of employed men)

- 72.3 per cent of domestic workers around the world (55 million) were at significant risk of losing their jobs and incomes due to lockdowns and the lack of effective social security coverage

- Women represent more than 70 per cent of those employed in health and social work. Despite forming the bulk of frontline workers who face direct risks of responding to the virus, they tend to be engaged in lower skilled and lower-paid jobs in this sector.

Young people, recently out of education and at an early stage in their working life tend to be over-represented in precarious jobs and hard-hit industries (Lee et al, 2020). On the job learning, which is particularly relevant to young labour market entrants, has been highly disrupted (ILO 2020: 11). Additionally, there are bleak prospects for 2020 graduates trying to enter the labour market. Young people who are recent entrants to the labour market are cheaper to fire so at higher risk of being laid off. In sectors badly affected by severe declines in economic output, specifically accommodation and food services, wholesale and retail trade, and manufacturing, almost three quarters of the youth working in them (131 million) are informally employed. The largest number of this vulnerable group are found in upper-middle-income countries where 54 million informally employed young people were working in the hardest hit sectors at the onset of the COVID-19 crisis (ILO 2020:9).

\section{Impact on the labour market in specific countries}

Across the globe the COVID-19 health emergency is turning into a severe economic crisis with unemployment rising to levels not seen since the previous global financial crisis in 2008-9 (OECD, 2020(a)). The OECD-wide unemployment rate rose from 5.2 per cent in February to 8.4 per cent in May 2020. During the first three months of the crisis, total worked hours have collapsed on average 10 times more than in the same period of the global financial crisis (ILO 2020 (b): 49). Women report decreased productivity because of reduced hours and increased care demands. The literature provides the analysis above of global trends, which may be universally relevant. More limited country specific data with examples supplements this:

During the first two months of the COVID-19 crisis in Mexico, the country experienced one of the largest drops (a fall of 22 per cent) in hours worked, among all OECD countries for which data are available (OECD,2020(a)). Latin America and the Caribbean is the region most affected in the world in terms of reduction of hours worked and income from labour (Maurizio et al, 2020). It was a novel effect of this crisis that job loss has been more intense among self-employed workers than among wage earners, and deeper among informal than formal workers. (Maurizio et al, 2020). Low-income youth holding formal jobs fared better than youth holding informal jobs. Although both informal and formal workers were affected by reductions in their earnings these appear to have dropped more for those with an informal job. In addition, formal workers were more optimistic about keeping their jobs than youth in the informal sector (Cardenas et al, 2020). 
Workers employed in factories producing products for export (largely to the US) initially lost work with factory closures. In response to growing pressure from US manufacturers and the US government to make it legal for Mexican factories involved in supply chains to reopen and despite not being designated essential services, many maquila factories continued manufacturing products for export to the US, putting workers' health at risk and, exposing many to the virus. The consequences of that decision for maquila workers ${ }^{2}$ and their communities will become apparent (Maquila Solidarity Network, 2020).

In South Africa the nationwide lockdown enacted in March 2020 reduced activity in mining and industry, and brought the tourism, entertainment and passenger transport sectors to a near standstill (OECD, 2020 (b). Growth has collapsed, unemployment is rising. There has been a 40 per cent decline in active employment (Zizzamia et al, 2020). Since half of this comprises job terminations, it is likely there will be persistent labour market effects. In the initial stages of the pandemic vulnerable groups are disproportionately affected, and Zizzamia's study of the labour market estimates that 20-33 per cent of job losers fall into poverty. Only 20 per cent of those temporarily not working received the intended state relief, while a third of job losers had no access to any major form of social protection (Zizzamia et al, 2020). The tourism sector was hard hit by the pandemic and resulting containment measures, yet it has good potential to contribute to the economy and future growth in employment (OECD, 2020 (b).

In the Philippines, some sectors temporarily halted by the lockdown face medium risk of job disruption as they may recover after some transition period. These include water supply and waste management activities; construction; wholesale and retail trade; information and communication; financial and insurance activities; real estate activities; and professional and scientific services. High-risk sectors consist of industries that are least likely to remain operative with containment measures in place or are already experiencing sharp slumps in demand due to the pandemic. These sectors include manufacturing, transportation and storage, accommodation and food service activities, and arts, entertainment and recreation. Overall, wholesale and retail trade, transportation and storage, construction, and accommodation and food services embed the largest number of workers at risk of job disruption; about 7.8 million workers, one-third of which are women (ILO, 2000 (c): 20)

Also, in the Philippines, the Business Process Outsourcing (BPO) industry is a major part of the economy with a contribution second only to remittances brought in via migration. The Philippines has the world's largest concentration of call centre workers who provide services for overseas corporations (such as facilitating travel and insurance cover, customer support for technology, and telehealth services). The sector employs 1.3 million people in over 1000 firms (Thompson, 2020). Though the IT and Business Process Association of the Philippines has tried to attract more highly skilled work, just $15 \%$ of the BPO workforce were employed in such roles before the pandemic (Thompson, 2020). As the industry has grown pay and conditions have declined, with an estimated $40 \%$ of the workforce now employed on precarious 'floating' / 'no-work-no-pay' status. Floating workers are not eligible for working benefits. Women have long dominated call centre activities, while BPO is one of the few workplaces where Filipino LGBTQ+ workers can find safe employment, so these groups are heavily impacted.

Those employed in maquiladora assembly factories on Mexico's northern border with the United States 
COVID-19 has disrupted the BPO industry and the overseas corporations it serves. Although BPO activities have been exempt from closure during quarantine periods, the closure of public transport leaves many employees unable to travel to work. Insufficient home internet connectivity leaves others unable to work from home. Quarantine restrictions meant BPO businesses were unable to maintain normal staffing levels, particularly at the onset. Later some businesses provided on-site accommodation to allow workers with quarantining family members or those without caring duties to continue to work and be paid. However workers report this 'accommodation' includes sleeping at work-stations or sharing hotel rooms in which COVID-19 positive workers are not separated out and hence are unsafe (Thompson, 2020). The responses from the foreign businesses using call centres vary. Some pulled out of using these outsourced facilities. Some sought to facilitate homeworking, shipping IT equipment to workers' homes. As the average Manila household has 4-5 people with "poor yet expensive internet connection" (Ocampo and Yamagishi, 2020: 8), homeworking is unsuitable for many. Subsequently COVID19 has been met with economic protectionism and the tightening of borders. Some companies are re-shoring BPO activities, taking advantage of newly unemployed workforces in places with a wider penetration of broadband and home office equipment, and where impacts of future lockdowns are more predictable.

In Indonesia state recognition for informal workers is minimal; only those who have formal working arrangements with and receive income from an employer are recognised as workers. Yet employment arrangements for various types of work in Indonesia, such as domestic work, are often made informally and verbally without a written contract (Octavia, 2020). Prevailing social norms disguise the existence of an employment relationship between the worker and the employer, leaving the worker with little to no legal protection. A second popular type of informal work is own-account work, in which workers are self-employed without an employer to whom they report. Examples of such occupations include street vendors, as well as motorcycle taxi drivers, classified as independent contractors by platform companies through which they obtain work.

Before the pandemic, over 70 million workers, more than half of Indonesia's workforce, earned their livelihoods in the informal sector. Although not all informal workers are poor and not everyone who is poor works in the informal sector, the informal sector in Indonesia is often linked to vulnerable employment and unstable income (Octavia, 2020). Unregistered, unregulated, and unprotected, informal workers in Indonesia have been disproportionately affected by the economic repercussions of the COVID-19 pandemic. Even before the pandemic, data from the Central Bureau of Statistics (2016, cited in Octavia, 2020) showed that most of Indonesia's poor (46.8 per cent) earn their livelihoods in the informal sector or are unemployed (37.7 per cent); just 15.5 per cent of the poor are employed in the formal sector. During lockdown conditions in Indonesia with more people staying at home, changes in mobility and consumption behaviours, the earnings of informal workers such as street vendors and transport drivers have been severely disrupted. Other informal industries that require in-person connections, including domestic work, were hard-hit. Casual workers in the tourism industry were put out of work entirely as businesses continued to decline. The average daily earnings of informal workers have fallen (by as much as 80 per cent though actual figures vary across different occupations). As substantial layoffs push people out of the formal sector and into informal work, making the informal labour market more competitive, these losses in income are further increased. 


\section{Changing skill demands}

The global labour market was already challenged to respond to pressures of the growing youth population, the rise of computing technologies and the political and social imperatives for countries to decarbonise their economies. COVID-19 has made this 'tri-lemma' more urgent still.

\section{On-line Education}

As the world enters a phase of gradual recovery, it is important to limit the impact of the current crisis on education systems and to leverage education and skills development as an effective and efficient means for economic revival. The crisis has revealed the weakness of traditional education systems. As countries prepare for gradual reopening of education, solutions for distance learning such as revised teacher training and the development of digital curriculum content are appropriate to strengthen on-line learning (UNESCO, 2020:11). Investing in local education technology ecosystems including local content production, development and maintenance of online platforms, services to schools, data protection and security, infrastructure development and capacity building and training services would all underpin this system of education.

\section{Digitalisation}

The digital economy is developing rapidly (if unevenly) across countries and it is becoming increasingly important for developing economies to adapt to a rapidly changing skills landscape both in terms of levels of employment (as some tasks become redundant through automatization) and occupational structure (as the skills demand shifts) (Banga \& te Velde, 2018). Service sectors such as accommodation, retail and sales that were heavily impacted by the pandemic are less exposed to risk from routinisation because sales and public facing roles require interpersonal and communication skills. In industry, digital technologies will make some jobs redundant for example in the automotive sector in India, South Africa and Mexico where use of robots is concentrated. Overall automatization of processes is more likely to affect overall jobs through substituting for specific tasks in a job, freeing up workers to perform other tasks or new tasks that will require new skills (Banga \& te Velde, 2018:4). Banga and te Velde (2018) assess current skills-readiness of developing economies under different task categories, using information on education, ICT employment and skills shortages. Developing countries are significantly less digitally ready, in part because their technical tertiary education and vocational training rates are lagging. They also lag behind in analytical and interpersonal skills. Specifically, in South Africa there appears to be an overall surplus of technical skills, but a skills shortage of problem-solving skills, social skills and critical-thinking skills (Banga \& te Velde, 2018:4).

\section{Green Economy}

COVID-19 has highlighted the choice between two possible recovery pathways: one which is low-carbon, and one which locks in catastrophic climate change. The low-carbon transition will require adapting and changing existing sectors and industries, creating new occupations requiring new skills, as other skills become obsolete (Genscu et al, 2020). The low carbon 
transition implies significant changes in the type of skills needed and the jobs available in specific locations. Countries at the forefront in developing skills for the low-carbon transition will create new global employment opportunities for their own citizens, and attract migration of workers from elsewhere, building trade links in the long term (Genscu et al, 2020:8). Education and skills development systems have an inertia that is ill-suited to the rapidity and unpredictability of the low-carbon transition. Gaps between education and training systems and industry needs persist; this needs to be narrowed with young people and new entrants to the labour market bringing relevant combination of knowledge and aptitudes. Skills development and education for the lowcarbon transition must disaggregate for and target different skill levels and age groups - from young people learning advanced technology skills in frontier industries to experienced manual workers in declining industries - as well as for those currently in informal employment (Genscu et al, 2020:8).

ILO (2019) defines "green jobs" as decent jobs that contribute to preserving or restoring the environment, be they in traditional sectors such as manufacturing and construction, or in new, emerging green sectors such as renewable energy and energy efficiency. Climate change and environmental degradation reduce productivity and destroy jobs, and their effects fall disproportionately on the most vulnerable. Green jobs help to improve efficiency in the use of energy and raw materials, limit greenhouse gas emissions, minimize waste and pollution, protect and restore ecosystems, and support adaptation to the effects of climate change (ILO, 2016 cited in ILO, 2019). In two detailed rounds of research (2010, repeated and updated in 2018) ILO has made detailed analysis of the scale of need for reskilling and upskilling to realize the employment potential of the transition to environmental sustainability (the "green transition)."). And of the changes in occupations, skills gaps and skills shortages in meeting the skills demand of the green transition - the skill shortages for green jobs (ILO, 2019). The essential process of transition to the green economy may disrupt labour markets and will require reskilling and upskilling of workers to reduce the risk of rising unemployment, poverty and inequality.

Reskilling workers as economies gradually start to reopen post COVID-19 presents an opportunity to simultaneously address the impact that the transition to energy sustainability by 2030 will have on employment. Many new jobs will be created, and some existing workers will need to be reskilled. While for others whose job is lost, reskilling for a new occupation required. ILO analysis $(2019)^{3}$ shows that almost 25 million jobs will be created and nearly 7 million lost globally. Of the latter, 5 million can be reclaimed through labour reallocation - that is, 5 million workers who lose their jobs because of contraction in specific industries will be able to find jobs in the same occupation in another industry within the same country. This means that between 1 and 2 million workers are likely to be in occupations where jobs will be lost without equivalent vacancies arising in other industries and will require reskilling into other occupations. It also means that massive investment will be needed to train workers in the skills required for almost 20 million new jobs (ILO, 2019:9).

Indonesia, the Philippines, and South Africa are found amongst the countries studied within this ILO analysis and therefore contribute to the global picture of the shift in skill sectors anticipated.

${ }^{3}$ Skills for a Greener Future https://www.ilo.org/skills/pubs/WCMS_732214/lang--en/index.htm 
The detail of this global picture as illustrated within

- Occupations most in demand across industries in a global energy sustainability scenario, 2030 ((ILO, 2019: 9, Figure 3) which shows that

- The greatest number of job losses (globally) is expected in the category of science and engineering professionals. The six uppermost categories in which greatest increase in demand for occupations is expected are: electrical and electronic trades workers; sales workers; metal machinery and related trades workers; market oriented skilled agricultural workers; labourers in mining, construction, manufacturing and transport; building and related trades workers, excluding electricians.

- Occupations most susceptible to job destruction and reallocation across industries in a global circular economy scenario, 2030 (ILO, 2019: 10, Figure 4) are sales workers; metal, machinery and related trades workers; and science and engineering professionals - although redeployment will absorb only a small part of the overall number of job losses (see above). Hence it is expected these shifts will necessarily bring demand for some new skills, and skills updating for a combination of new jobs and new jobs designed for laid-off workers.

\section{Opportunities for restructuring labour markets}

In terms of responding to the pandemic the literature distinguishes between measures designed to protect workers and households from the immediate income shock and support firms to retain workers and stay afloat in the relief phase. And the recovery phase when economies start to reopen and firms have an opportunity to adapt to a new normal, becoming more resilient (Carranza et al, 2020).

Policies to support businesses adapt may include support to firms to transition to digital platforms including business to consumer (B2C) and business to business (B2B). It also includes more traditional measures like improving access to or lowering the cost of basic infrastructure and services required for production and commercialization (water, electricity, transportation, etc.,) as well as providing investment capital rather than just short-term working capital. (Carranza et al, 2020:11). The latter is particularly relevant for SMEs in the informal sector especially as a substantial part of the global workforce is employed in informal private sector jobs (see Section 2 above). For many low and middle-income countries, there is a small, but rapidly closing, window of opportunity to prepare for the subsequent employment crisis. Since most countries do not have effective mechanisms in place to reach most informal businesses and workers, solutions need to be pragmatic and will often be imperfect (Carranza et al, 2020:27).

It is crucial to get the timing right for tailored support to the COVID-19 generation of workers. The longer they are out of work or underemployed, the more difficult it will be to reverse the adverse impacts of the crisis. In previous crises, workers who started looking for a job during a recession, experienced significant negative impacts on employment and income (scarring) compared to those with better timing. These effects tend to be especially prevalent among low-skilled and more vulnerable workers. Recent graduates, first-time jobseekers, and workers who lost their jobs during this crisis form the core of this COVID-19 generation. Many 
women (who also carry a disproportionate share of family and household responsibilities, particularly in the face of school closures) are at particularly high risk of being scarred. They should be the main target of policies to avoid long-term impacts (Carranza et al, 2020:29).

\section{Training to reflect post pandemic needs}

Fundamentally education and literacy levels, are an indication of the quality of the labour force and differ considerably between lower middle-income countries (less than $75 \%$ of the population in 2017 were literate) while the literacy rate in upper middle-income countries is almost $95 \%$ (van der Hoeven, 2020). During lockdown and the aftermath, most fiscal responses were directed at immediate goals aimed to save lives and livelihoods. Education benefited only to a very limited extent. Analysis of the fiscal measures taken to stimulate economies across 192 countries, show relatively low investments in education and training. Supplementary allocations to education seem to be particularly low in high-income and upper middle-income countries $(0.74$ per cent and 0.62 per cent, respectively), while these figures are 1.56 per cent for sub-Saharan Africa (UNESCO, 2020:9). This is short sighted, and UNESCO argues for increasing investment in education.

Technical and Vocational Education and Training (TVET) can be well-placed to develop important skills needed to mitigate the impacts of the COVID-19 pandemic which has emphasised the crucial importance of many practical service sector jobs. These essential workers include health care professionals, child and elder careworkers, grocery store employees, logistics workers, and ICT support staff, among others. In theory TVET's focus on practical skills, and its potential to deliver short-term, targeted, and modular training could be harnessed to rapidly upskill workers in essential sectors and to reskill individuals to engage in the response. However, this same focus on practical skills and work-readiness makes remote learning particularly challenging. Practical skills are often acquired through learning-by-doing, which occurs in school-based workshops and learning laboratories or through gaining hands-on experience in work environments. Remote learning approaches are a weak substitute for such practical exercises (Hoftijzer et al, 2020).

In many countries, TVET systems face challenges in responding quickly and adequately to changing skills demand. To help address the substantial economic disruptions caused by the pandemic, it will be especially important that bottlenecks preventing demand-responsive training provision are addressed and that training programmes and skill development systems are appropriately reimagined, reset and reworked. TVET system reforms that reinforce the demandorientation of programmes should be undertaken, so these can respond quickly to shifting patterns of skill demand. In particular it will be essential to:

- design new or expand current programs to address emerging skill needs, in collaboration with employers

- work in partnership with employers to provide rapid and modular skills training to idle and unemployed workers (Hoftijzer et al, 2020:2).

Whether a switch to remote learning can materialise at all depends on connectivity and a platform so it is likely that large parts of the TVET student population in low- and middle-income countries where such mechanisms do not exist, and for TVET students in disadvantaged 
households in higher-income countries who will struggle with connectivity significant barriers to skill development will remain. Investments in renewable energy and new technologies are both a sectoral response where expanding businesses have the capacity to absorb high shares of the youth employment market; and a means to improving online learning (ILO, 2020:15). To realise the potential benefits of online learning and to develop this future for home-based employment opportunities it is crucial to boost investments in broadband connectivity and investment in online learning with, ICT equipment and digital skills for students and teachers/trainers, and quality curricula tailored to a virtual audience.

\section{References}

Banga, K. and te Velde, D.W. (2018) Skill needs for the future Pathways for Prosperity Commission Background Paper Series; no. 10. Oxford, United Kingdom. https://pathwayscommission.bsg.ox.ac.uk/skill-needs-for-the-future

Cardenas et al (2020) How did COVID-19 affect youth workers in Mexico? Here's what we found (World Bank blog)

https://blogs.worldbank.org/jobs/how-did-covid-19-affect-youth-workers-mexico-heres-what-wefound

Carranza, E., Farole, T., Gentilini, U., Morgandi, M., Packard, T., Santos, I.; Weber, M., (2020.) Managing the Employment Impacts of the COVID-19 Crisis : Policy Options for Relief and Restructuring. Jobs Working Paper; No. 49. World Bank, Washington, DC.

https://openknowledge.worldbank.org/handle/10986/34263 License: CC BY 3.0 IGO.

Gencsu, I., Parsons Grayson, A., Mason, N., \& Foresti, M., (2020) Migration and skills for the low-carbon transition: ODI Working Paper 585

https://www.odi.org/sites/odi.org.uk/files/resource-documents/migration_and_skills_for_the_lowcarbon_transition_final_2.pdf

Hoftijzer, M., Levin, V., Santos, I., and Weber, M., (2020) TVET Systems' response to COVID-19: Challenges and Opportunities World Bank

https://openknowledge.worldbank.org/handle/10986/33759

ILO Skills for a Greener Future (2019)

https://www.ilo.org/skills/projects/WCMS_706922/lang--en/index.ht

ILO Policy Brief May 2020 (a)

Preventing exclusion from the labour market: Tackling the COVID-19 youth employment crisis https://www.ilo.org/emppolicy/pubs/WCMS_746031/lang--en/index.htm

ILO Monitor (2020, (b): COVID-19 and the world of work. Second edition Updated estimates and analysis April 2020 https://www.ilo.org/global/about-the-ilo/WCMS_740877/lang--ja/index.htm 
ILO (2020 (c) COVID-19 labour market impact in the Philippines

https://www.ilo.org/wcmsp5/groups/public/---asia/---ro-bangkok/---ilo-

manila/documents/publication/wcms_762209.pdf

Lee, S., Schmidt-Klau D., Verick, S., (2020) The Labour Market Impacts of the COVID-19: A

Global Perspective Indian Society of Labour Economics 2020

link.springer.com/article/10.1007/s41027-020-00249-y

Maquila Solidarity Network (2020) Tracking the impact of the COVID-19 pandemic on Mexican

Maquila workers

https://www.maquilasolidarity.org/en/our-work/tracking-impact-covid-19-pandemic-mexican-

maquila-workers

Maurizio et al, (2020) Impact on the labour market and income in Latin America and the

Caribbean ILO Technical Note

https://www.ilo.org/wcmsp5/groups/public/---americas/---ro

lima/documents/publication/wcms_75669

Octavia, J. (2020) Building Back Better: COVID-19 and Informal Workers in Indonesia London School of Economics

https://blogs.Ise.ac.uk/seac/2020/12/15/building-back-better-covid-19-and-informal-workers-inindonesia/

OECD Employment Outlook 2020 (a): Worker security and the COVID-19 crisis How does Mexico compare? http://www.oecd.org/employment-outlook/

OECD Economic Survey of South Africa, 2020 (b)

http://www.oecd.org/southafrica/south-africa-covid-19-pandemic-raises-the-urgency-of-structuralreforms.htm

Thompson, M., (2020) COVID-19 and the Philippines' outsourcing industry London School of Economics

https://blogs.Ise.ac.uk/seac/2020/09/22/covid-19-and-the-philippines-outsourcing-industry/

van der Hoeven, R., (2020) Growth and labour markets in middle-income countries Development Matters Building resilience Growth, Labour, Middle Income Trap

International Institute of Social Studies at Erasmus University, The Hague \& Member of the Committee for Development Policy of the United Nations

https://oecd-development-matters.org/2020/12/04/growth-and-labour-markets-in-middle-incomecountries/

Women Enabled International (2020) COVID-19 at the Intersection of Gender and Disability: Findings of a Global Human Rights Survey, March to April 2020, Women Enabled International https://womenenabled.org/blog/covid-19-survey-findings/

Work and Opportunities for Women (WOW) Report No 53 Implications of COVID-19 on women informal workers 
https://assets.publishing.service.gov.uk/government/uploads/system/uploads/attachment_data/fil e/911533/Query-53-covid-and-women-informal-workers.pdf

Zizzamia, R., Jain, R., Budlender, J., Bassier, I., (2020) The labour market and poverty impacts of COVID-19 in South Africa Centre for the Study of African Economies Working Paper 2020-14 https://www.csae.ox.ac.uk/papers/the-labor-market-and-poverty-impacts-of-covid-19-in-southafrica

\section{Suggested citation}

Enfield, S., (2021). Covid-19 impact on employment and skills for the labour market. K4D Helpdesk Report. Brighton, UK: Institute of Development Studies. DOI: 10.19088/K4D.2021.081

\section{About this report}

This report is based on six days of desk-based research. The K4D research helpdesk provides rapid syntheses of a selection of recent relevant literature and international expert thinking in response to specific questions relating to international development. For any enquiries, contact helpdesk@k4d.info.

K4D services are provided by a consortium of leading organisations working in international development, led by the Institute of Development Studies (IDS), with Education Development Trust, Itad, University of Leeds Nuffield Centre for International Health and Development, Liverpool School of Tropical Medicine (LSTM), University of Birmingham International Development Department (IDD) and the University of Manchester Humanitarian and Conflict Response Institute (HCRI).

This report was prepared for the UK Government's Foreign, Commonwealth and Development Office (FCDO) and its partners in support of pro-poor programmes. Except where otherwise stated, it is licensed for non-commercial purposes under the terms of the Open Government Licence v3.0. K4D cannot be held responsible for errors, omissions or any consequences arising from the use of information contained in this report. Any views and opinions expressed do not necessarily reflect those of FCDO, K4D or any other contributing organisation.

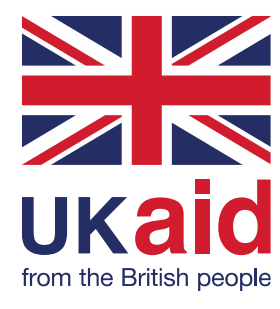

(c) Crown copyright 2021. 